(อ)

\section{OPEN ACCESS}

- Additional material is published online only. To view, please visit the journal online (http://dx.doi.org/10.1136/ bcr-2020-240650).

Division of Cardiology, University of Alberta, Mazankowski Alberta Heart Institute, Edmonton, Alberta Canada

\section{Correspondence to}

Dr Janek Manoj Senaratne; janeks@ualberta.ca

Accepted 17 February 2021

\title{
Type A aortic intramural hematoma
}

\author{
Arjun Kumar Gupta 지 , Janek Manoj Senaratne
}

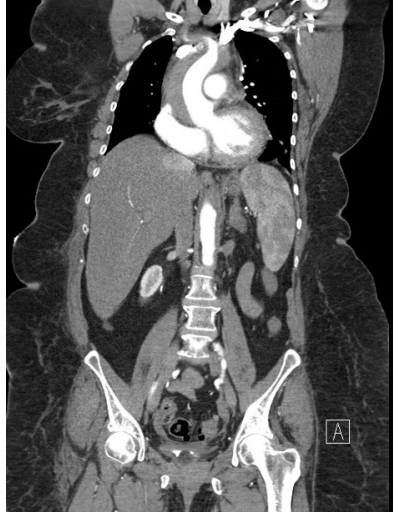

\section{DESCRIPTION}

Aortic intramural haematoma (IMH) is an acute aortic syndrome which constitutes $5 \%-20 \%$ of all acute aortic syndromes. ${ }^{1}$ It is defined as a contained haemorrhage into the media without rupture of the intima. ${ }^{2}$ It is thought to either be due to rupture from a penetrating atherosclerotic ulcer that then thromboses the false lumen or due to spontaneous rupture of a vasa vasorum. $\mathrm{IMH}$ has been reported to progress to acute aortic dissection in up to $88 \%$ of patients when the ascending aorta is involved. ${ }^{3} \mathrm{IMH}$ also has a higher risk of aortic rupture than aortic dissection due to the outer media being thinner. We present a case where aortic IMH was initially suspected on coronary angiography and subsequently confirmed on ancillary imaging.

A 61-year-old woman with a history of hypertension, hyperlipidaemia, type 2 diabetes, previous non-ST elevation myocardial infarction and previous smoking presented to a rural emergency department (ED) with atypical chest pain. Her vital signs in the ED were a heart rate of 55, right arm blood pressure of $118 / 57$, left arm blood pressure of $115 / 54$, oxygen saturation of $95 \%$ on 2 -litre nasal prongs and a temperature of $36.4^{\circ} \mathrm{C}$. ECG revealed sinus bradycardia with old inferior q-waves and lateral ST-depression and her troponin I was elevated at 0.10. Chest X-ray was not of good quality to evaluate the mediastinum (online supplemental figure 1). Unfortunately, a d-dimer was not measured at the rural ED and a bedside echocardiogram was unavailable. The patient was therefore treated as

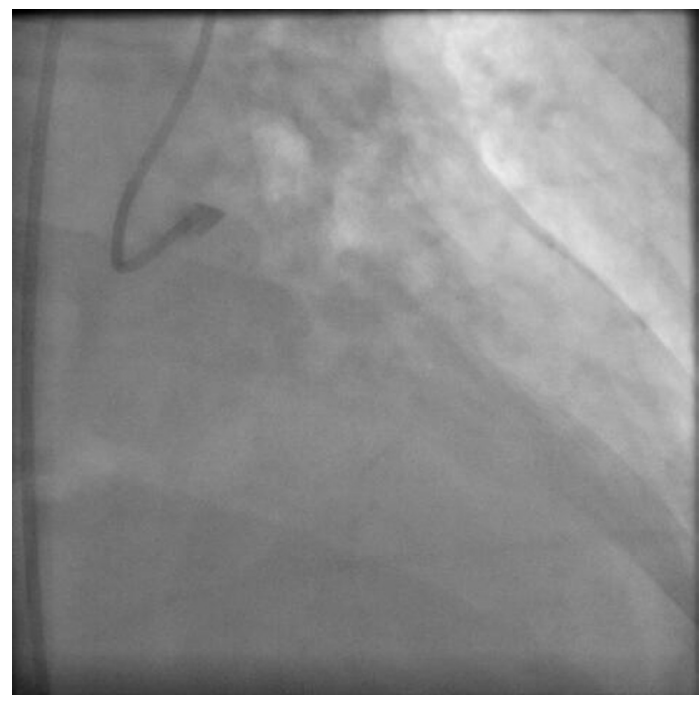

Figure 1 Coronary angiography with injection into penetrating atherosclerotic ulcer.
Figure 2 CT Angiogram Coronal View Demonstrating Type A IMH Extending from the Aortic Root.

a non-ST elevation myocardial infarction transferred for angiography. Coronary angiography revealed no obstructive coronary artery disease, however, initial left coronary artery engagement was suspicious for a possible penetrating atherosclerotic ulcer (figure 1). Root aortogram was performed, which revealed no evidence of dissection. Given this, the patient went on to have a CT angiogram of the chest which revealed a large type A IMH extending from the aortic root to the level of the left renal artery (figure 2).

The patient was subsequently taken for emergent aortic repair. Intraoperatively she had significant bleeding and left main coronary button failure requiring coronary artery bypass grafting. Postoperatively she developed multiorgan failure and died on post-operative day 3 .

Learning points

Aortic intramural haematomas are associated with penetrating atherosclerotic ulcers.

- D-dimer should be considered in patients presenting with chest pain to rule-out causes such as aortic dissection/haematoma and pulmonary embolism.

- Aortic intramural haematomas may not be associated with a widened mediastinum on chest X-ray and may have a normal aortic root shot on coronary angiography.

- Bedside echocardiogram should be considered in chest pain/troponin elevation presentations to identify regional wall motion abnormalities as well as non-coronary pathologies such as aortic dissections/intramural haematomas. 
Contributors AKG and JMS both examined and treated the patient. AKG and JMS shared equal parts in the writing and preparation of the manuscript. Both authors approve it for publication.

Funding The authors have not declared a specific grant for this research from any funding agency in the public, commercial or not-for-profit sectors.

Competing interests None declared.

Patient consent for publication Not required.

Provenance and peer review Not commissioned; externally peer reviewed.

Open access This is an open access article distributed in accordance with the Creative Commons Attribution Non Commercial (CC BY-NC 4.0) license, which permits others to distribute, remix, adapt, build upon this work non-commercially, and license their derivative works on different terms, provided the original work is properly cited and the use is non-commercial. See: http://creativecommons.org/ licenses/by-nc/4.0/.

\section{ORCID iD}

Arjun Kumar Gupta http://orcid.org/0000-0001-7159-8933

\section{REFERENCES}

1 Erbel R, Aboyans V, Boileau C, et al. 2014 ESC guidelines on the diagnosis and treatment of aortic diseases: document covering acute and chronic aortic diseases of the thoracic and abdominal aorta of the adult. The task force for the diagnosis and treatment of aortic diseases of the European Society of cardiology (ESC). Eur Heart J 2014:35:2873-926

2 Coady MA, Rizzo JA, Elefteriades JA. Pathologic variants of thoracic aortic dissections. penetrating atherosclerotic ulcers and intramural hematomas. Cardiol Clin 1999;17:637-3.

3 Alomari IB, Hamirani YS, Madera G, et al. Aortic intramural hematoma and its complications. Circulation 2014;129:711-6.

Copyright 2021 BMJ Publishing Group. All rights reserved. For permission to reuse any of this content visit

https://www.bmj.com/company/products-services/rights-and-licensing/permissions/

BMJ Case Report Fellows may re-use this article for personal use and teaching without any further permission.

Become a Fellow of BMJ Case Reports today and you can:

- Submit as many cases as you like

- Enjoy fast sympathetic peer review and rapid publication of accepted articles

- Access all the published articles

Re-use any of the published material for personal use and teaching without further permission

Customer Service

If you have any further queries about your subscription, please contact our customer services team on +44 (0) 2071111105 or via email at support@bmj.com.

Visit casereports.bmi.com for more articles like this and to become a Fellow 